\title{
Potret Perempuan dalam Film Tilik Karya Wahyu Agung Prasetyo
}

\author{
Siti Masyitoh1, Muhammad Muzaki Adnan2* \\ 1,2*Pondok Pesantren Syamsul Ulum Muhammadiyah Bandung; ${ }^{1}$ masyitoh16@gmail.com, \\ 2*muzakiadnan15@gmail.com
}

*Penulis Korespondensi

Artikel Dikirim: 10 Desember 2020;

Artikel Diterima: 19 Mei 2021;

Artikel Dipubikasikan: 21 Juni 2021

\begin{abstract}
Abstrak: Penelitian ini bertujuan untuk menjelaskan potret perempuan dalam film Tilik. Perempuan direpresentasikan dengan berbagai cara dalam film tersebut, misalnya sebagai kepala desa (Bu Lurah), sebagai istri (Bu Tejo, Bu Tri), atau individu (Dian, Yu Ning, Yu Sam). Namun, dalam film ini menggambarkan kekuatan perempuan dengan cara yang negatif. Sumber utama kekuatan mereka berasal dari bergosip, pamer, dan melanggar aturan. Melalui metode semiotika Roland Barthes, penelitian ini mengungkapkan potret perempuan melalui lima sisi yang ditampilkan. Terdapat lima temuan pada penelitian ini. Pertama, perempuan sebagai tukang gosip. Kedua, perempuan sebagai tukang pamer. Ketiga, pengaruh internet terhadap ibu-ibu. Keempat, perempuan yang belum menikah di usia matang menjadi bahan fitnah. Kelima, perempuan mampu bekerja di ranah publik. Kelima temuan ini bukanlah suatu usaha peneliti untuk melakukan generalisasi terhadap perempuan. Dengan kelima unsur yang dimiliki perempuan, ternyata menyimpan makna yang bisa diambil sebagai pelajaran hidup. Akan tetapi, selain dari nilai negatif yang muncul dalam film tersebut, terdapat pula nilai positif yang dapat diambil diantaranya tradisi masyarakat desa yang saling peduli, gotong royong dan memiliki pribadi solutif ketika terjadi dinamika. Dimana tradisi ini sulit ditemukan dalam kehidupan perempuan di kota-kota besar, juga pesatnya teknologi dikalangan ibu-ibu, serta dengan menjadi perempuan berkarier dapat membentuk pribadi yang tangguh dan mandiri.
\end{abstract}

Kata Kunci: Film, Tilik, perempuan, Gosip

\begin{abstract}
Abstrak: This study aims to explain the portrait of women in the film Tilik. women are represented in various ways in the film, for example as a village head (Bu Lurah), as a wife (Bu Tejo, Bu Tri), or an individual (Dian, Yu Ning, Yu Sam). However, this film depicts the power of women in a negative way. Their main source of strength comes from gossiping, showing off, and breaking the rules. Through Roland Barthes' semiotic method, this research reveals the portrait of women through the five sides shown. There are five findings in this study. First, women are gossipers. Second, women are show-offs. Third, the internet's influence on mothers. Fourth, unmarried women at ripe age become materials for slander. Fifth, women are able to work in the public sphere. These five findings are not an attempt by researchers to generalize about women. With the five elements that women have, it turns out that they have meaning that can be taken as life lessons. However, aside from the negative values that appear in the film, there are also positive values that can be taken including the tradition of villagers who care for each other, Collaboration (gotong royong) and have a solutive person when there is a dynamic. Where this tradition is difficult to find in the lives of women in big cities, also the rapidity of technology among mothers, as well as by becoming a career woman can form a tough and independent person.
\end{abstract}

Keywords: Gossip, Movies, Tilik, Women.

\section{Pendahuluan}

Menurut Effendy (Effendy, 1986) film merupakan media komunikasi yang bersifat audio visual untuk menyampaikan suatu pesan kepada sekelompok orang yang berkumpul di suatu tempat tertentu. Pesan dalam film dapat berbentuk apa saja, baik itu pesan moral, informasi, maupun sekadar 
hiburan saja. Pesan tersebut menggunakan mekanisme lambang-lambang yang ada pada pikiran manusia yang berupa isi pesan, suara, pecakapan, dan lain sebagainya.

Dalam kebanyakan film di Indonesia, perempuan menjadi objek perhatian. Kebebasan media menempatkan kaum perempuan sebagai objek dalam berbagai kesempatan dan alasan. Representasi perempuan dalam film menjadi penting mengingat film merupakan media komunikasi yang dapat mengubah pandangan seseorang (Hartoyo, 2018).

Film Tilik merupakan film pendek yang diproduksi Ravacana Film bekerja sama dengan Dinas Kebudayaan Daerah Istimewa Yogyakarta dan disutradai oleh Wahyu Agung Prasetyo. Film ini bercerita tentang ibu-ibu yang bergosip di atas truk ketika hendak menjenguk Bu Lurah yang sedang dirawat di rumah sakit. Tilik adalah bahasa Jawa yang berarti 'menjenguk'. Ibu-ibu berada di atas truk yang sedang melaju bergosip tentang Dian yang merupakan kembang desa. Dian digosipkan sebagai perempuan tidak baik karena ia dianggap sebagai seorang perempuan lajang yang baru bekerja namun sudah memiliki barang-barang mahal nan mewah dan ia kerapkali terlihat pergi bersama laki-laki.

Film pendek Tilik dirilis pada September 2018. Namun, pada 17 Agustus 2020, Ravacana Films merilisnya di kanal berbagi YouTube secara gratis untuk khalayak umum. Sejak saat itu, film pendek ini menjadi viral di media sosial. Per 21 Agustus 2020, film ini sudah ditonton lebih dari 2,4 juta orang dan kata Tilik juga ramai dicuitkan sebanyak 17 ribu kali di Twitter. Bahkan dalam kurun waktu sebulan, tepatnya pada 17 September 2020, penonton film Tilik mencapai 23 juta orang. Hal ini dikarenakan film Tilik menampilkan sisi sederhana yang terjadi dalam kehidupan masyarakat Indonesia, khususnya tentang budaya bergosip di kalangan kaum ibu (Kintoko, 2020).

Dalam film Tilik, terdapat karakter Bu Tejo yang begitu hidup, ia digambarkan banyak berbicara dan memengaruhi para ibu sambil bergosip di dalam truk yang hendak menjenguk Bu Lurah. Karakter $\mathrm{Bu}$ Tejo memang menarik perhatian karena banyak omong. Oleh karena itu, banyak yang berpendapat bahwa Bu Tejo adalah cerminan mayoritas ibu-ibu di Indonesia yang banyak bicara dan suka bergosip.

Terdapat juga tokoh perempuan lainnya dalam film Tilik, yaitu Dian. Dian merupakan tokoh perempuan yang menjadi bahan pergosipan atau pergunjingan. Dian dianggap sebagai perempuan yang tidak baik dikarenakan ia adalah perempuan yang cantik, sudah dewasa, dan bekerja namun belum juga menikah. Sehingga ia digunjingkan oleh kaum Ibu karena ia dikhawatirkan sebagai 'orang ketiga' atau perusak rumah tangga orang lain.

Selain tokoh Bu Tejo dan Dian, masih ada beberapa tokoh perempuan lainnya yang menjadi representasi atau potret perempuan dalam film Tilik. Oleh karena itu, penelitian ini bertujuan untuk mengetahui bagaimana potret perempuan dalam film Tilik karya Wahyu Agung Prasetyo.

Adapun metode yang digunakan dalam penelitian ini adalah content analysis (analisis isi). Analisis isi (content analysis) adalah penelitian yang bersifat pembahasan mendalam terhadap isi suatu informasi tertulis atau tercetak dalam media massa. Kemudian penelitian ini menggunakan pendekatan Semiotika Roland Barthes. Semiotika menurut Roland Barthes adalah ilmu mengenai bentuk (form). Studi ini mengkaji signifikasi yang terpisah dari isinya (content). Semiotika tidak hanya meneliti mengenai signifier (penanda) dan signified (petanda), tetapi juga hubungan secara keseluruhan. Teks yang dimaksud Roland Barthes adalah dalam arti luas. Teks tidak hanya berarti berkaitan dengan aspek linguistik saja. Semiotika dapat meneliti teks di mana tanda-tanda terkodifikasi dalam sebuah sistem. Dengan demikian, semiotika dapat meneliti bermacam-macam teks seperti, berita, film, iklan, fashion, fiksi, puisi, dan drama (Sobur, 2009). Selain itu, semiotika juga dapat digunakan sebagai alternatif untuk melihat komunikasi sebagai suatu proses (Balci, 2017).

Menurut Barthes, semiotika berfokus pada gagasan signifikasi dua tahap (two orders of signification). Signifikasi tahap pertama merupakan hubungan antara signifer (penanda) dan signified (petanda) di dalam sebuah tanda terhadap realitas eksternal dan Barthes menyebutnya sebagai 
denotasi dan konotasi. Denotasi ialah makna paling nyata dari tanda. Denotasi cenderung dideskripsikan sebagai makna literal dan jelas secara akal sehat dari suatu tanda. Makna denotasi suatu tanda disetujui secara luas oleh anggota budaya yang sama. Adapun pada signifikasi tahap kedua, Barthes menyebutnya dengan istilah konotasi, merupakan tahap yang berhubungan dengan isi. Konotasi digunakan untuk merujuk pada gabungan pemaknaan sosial budaya, ideologi, dan emosional dari tanda yang kemudian melahirkan mitos. Mitos adalah bagaimana kebudayaan menjelaskan atau memahami beberapa aspek tentang realitas atau gejala alam (Sobur, 2009).

Berikut ini merupakan skema Semiotika Barthes dari penjelasan yang ada di atas:

\begin{tabular}{|l|c|}
\hline $\begin{array}{l}\text { 1. Signifier } \\
\text { (Penanda) }\end{array}$ & $\begin{array}{c}\text { 2. Signified } \\
\text { (Petanda) }\end{array}$ \\
\cline { 1 - 2 } 3. Denotative Sign (Tanda denotatif) & Sistem linguistic \\
I. SIGINIFIER (Penanda) & II. SIGNIFIED (Petanda) \\
\hline III. CONNOTATIVE SIGN (Tanda Konotatif)
\end{tabular}

Adapun diskursus gender adalah salah satu contoh kerangka budaya penjelas tentang mitos. Mitos budaya membantu untuk memahami pengalaman seseorang dalam budaya, baik mengekspresikan maupun mengatur suatu konseptualisasi dalam budaya (Chandler, 2007). Dalam kerangka kajian budaya Barthesian, mitos, seperti konotasi, dilihat sebagai tatanan makna yang lebih tinggi. Barthes tidak melihat mitos-mitos budaya kontemporer sebagai sekadar penggambaran konotasi yang berpola, tetapi sebagai narasi ideologis.

Penelitian mengenai potret perempuan telah banyak dilakukan, diantaranya penelitian yang dilakukan oleh Hartoyo dan Tanjung (2018) yang membahas tentang potret perempuan Parangtritis dalam film Siti (Hartoyo, 2018). Penelitian ini bertujuan untuk menjelaskan representasi perempuan Parangtritis pada film Siti. Perempuan pesisir memegang peran penting dalam kegiatan ekonomi di darat. Sistem pembagian kerja pada masyarakat pesisir mengharuskan perempuan terlibat dalam ruang publik. Melalui metode semiotika Roland Barthes, penelitian ini mengungkap representasi perempuan pesisir melalui empat shot yang ditampilkan. Terdapat tiga temuan pada penelitian ini. Pertama, mobilitasnya pada ruang domestik. Perempuan pesisir tidak terlepas dari pengabdiannya kepada suami dan keluarga. Kedua, membantu penghasilan suami di ruang publik. Ketiga, ketidakberdayaan diri yang mengakibatkan terbatasnya perolehan pekerjaan di ruang publik. Ketiga temuan ini bukanlah suatu usaha peneliti untuk melakukan generalisasi terhadap potret perempuan pesisir. Dengan peran ganda yang dimiliki perempuan pesisir akibat desakan ekonomi, pada akhirnya perempuan pesisir tidak dapat melepaskan diri dari tanggung jawab di wilayah domestiknya.

Penelitian berikutnya dilakukan oleh Anggraini (Anggraini, 2016) yang mengangkat tentang stereotip perempuan dalam film Get Married. Penelitian ini bertujuan untuk mengetahui tanda-tanda dan pesan-pesan yang menstereotipekan perempuan dalam film Get Married. Metodologi penelitian yang digunakan deskriptif kualitatif. Hasil penelitian ini berdasarkan pada teori Semiotika Roland Barthes yang menganalisis menggunakan dua pemaknaan bertingkat, yaitu makna denotasi dan makna konotasi. Secara denotasi film Get Married menceritakan kehidupan 4 orang sahabat yang tidak 
mempunyai pekerjaan dan cerita seorang perempuan betawi tomboi yang sedang mencari jodoh. Sedangkan secara konotasi ditemukan bahwa pemahaman tentang mencari jodoh diartikan secara sempit. Diperlihatkan di film ini bahwa dengan mencarikan anak jodoh akan mempercepat untuk anaknya ke jenjang pernikahan. Film ini dapat dijadikan suatu pelajaran bagi kita agar dapat memaknai lagi kesetian dari persahabatan dan prilaku yang pada seorang perempuan tomboi. Menurut mitos perempuan di film ini masih menunjukan sifat perempuan Betawi yang asli karena meskipun dia menyukai lelaki dia tetap menunggu lelaki itu datang bukan mengejar dan menyatakan cinta duluan.

Berikutnya, penelitian serupa dilakukan oleh Perdana (Perdana, 2014) yang membahas tentang stereotip gender dalam film Anna Karenina. Penelitian ini bertujuan untuk mengetahui bagaimana stereotip gender ditampilkan dalam film Anna Karenina. Penelitian ini merupakan penelitian kualitatif dengan metoda analisis Semiotika Roland Barthes. Hasil penelitian menunjukkan bahwa dalam film Anna Karenina terdapat banyak tanda yang direpresentasikan melalui teks percakapan maupun teks gambar untuk mendukung stereotip bahwa perempuan bekerja di wilayah domestik dan pelabelan 'bad women' (perempuan tidak baik) di masyarakat.

Sementara itu, mengenai film Tilik itu sendiri belum banyak dilakukan. Baru ditemukan satu penelitian yang mengangkat film ini, yaitu penelitian yang dilakukan oleh Warsilah (2020) dengan judul "Transformasi Sosial Kultural Wong Ndeso Melalui Film Tilik dalam Konsep Lefebvre" (Warsilah, 2020). Hasil penelitian ini menunjukkan bahwa dari film ini digambarkan bahwa ada sesuatu yang berubah di ruang pedesaan, bahwa produksi 'obrolan' ala pedesaan saat ini tidak lagi sekedar tentang kegagalan panen, atau kematian bayi baru lahir, tetapi jauh melampaui spasial desa yakni tentang orang ketiga atau kerja selingkuh dari suami-suami di desa. Selain itu, revolusi digital tidak saja mempermudah kehidupan di pedesaan, misal untuk bersilaturahmi dan berinteraksi, menjual hasil produksi pertanian dan rumah tangga tidak perlu lagi melalui luring (tatap langsung) tetapi bisa melalui media daring seperti media sosial, Facebook, dan Twiter. Tetapi dibalik kemudahan melalui revolusi teknologi digital tersebut, ada implikasi negatif yang kini merubah kehidupan kaum ibu di pedesaan, yang ditampilkan dalam film Tilik dengan cara memproduksi gosip dan hoaks.

Berdasarkan tinjauan pustaka yang dilakukan oleh peneliti, maka pembahasan mengenai potret perempuan dalam film tilik belum ditemukan sehingga penelitian dengan judul "Potret Perempuan dalam Film Tilik karya Wahyu Agung Prasetyo" ini layak dilakukan.

\section{Pembahasan}

\subsection{Perempuan sebagai Tukang Gosip}

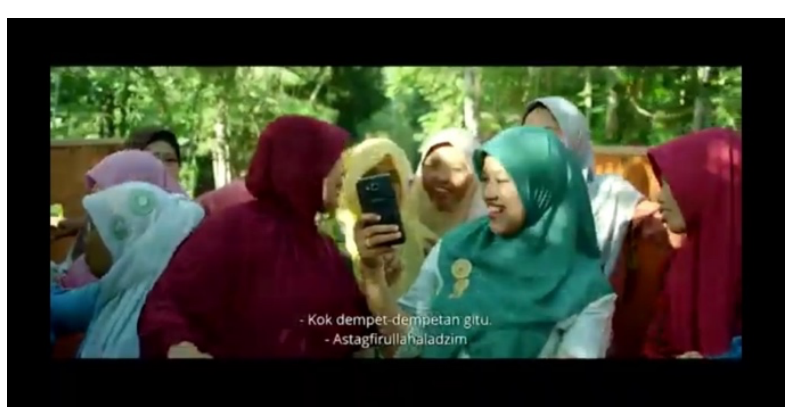

Gambar 2. Perempuan sebagai Tukang Gosip (Scene menit ke 00:00:40 - 00:03:00) 
Level denotasi. Bu Tejo memberikan informasi melalui Handphone kepada ibu-ibu. Level Konotasi. $\mathrm{Bu}$ Tejo membagikan informasi mengenai Dian di Facebook kepada Ibu-ibu sehingga Dian menjadi nyinyiran ibu-ibu. Adapun makna mitos dalam gambar tersebut adalah $\mathrm{Bu}$ Tejo memberikan informasi tentang Dian kepada ibu-ibu tentang pekerjaannya.

Mereka senang bergosip tentang Dian, seperti contoh dalam percakapan pada gambar, Bu Tejo bertanya "Dian iki gaweanyo opo yo? (Dian itu pekerjaannya apa?). “Aku ni pernah nyonangi Dian muntah-muntah pas wiki wayan wengi" (Eh, Aku jadi inget, Aku pernah mergoki Dian muntah malammalam) tutur Bu Tejo. Sosok Dian digambarkan sebagai perempuan lajang yang tidak berhijab. Ia digambarkan sebagai seorang pelakor (perebut laki orang), istilah seksis untuk "perempuan ketiga", dan ibu-ibu itu takut suaminya akan jatuh cinta pada Dian.

Terdapat penelitian di Selandia Baru menunjukan bahwa perempuan seringkali bergosip soal rumah tangga dan perselingkuhan (D. Jones, 1980). Tidak hanya itu, penggunaan gosip di perkotaan maupun di pedesaan cenderung menunjukan pola yang sama yaitu berkaitan dengan persaingan status sosial (S. E. Merry, 1984).

\subsection{Perempuan sebagai Tukang Pamer}

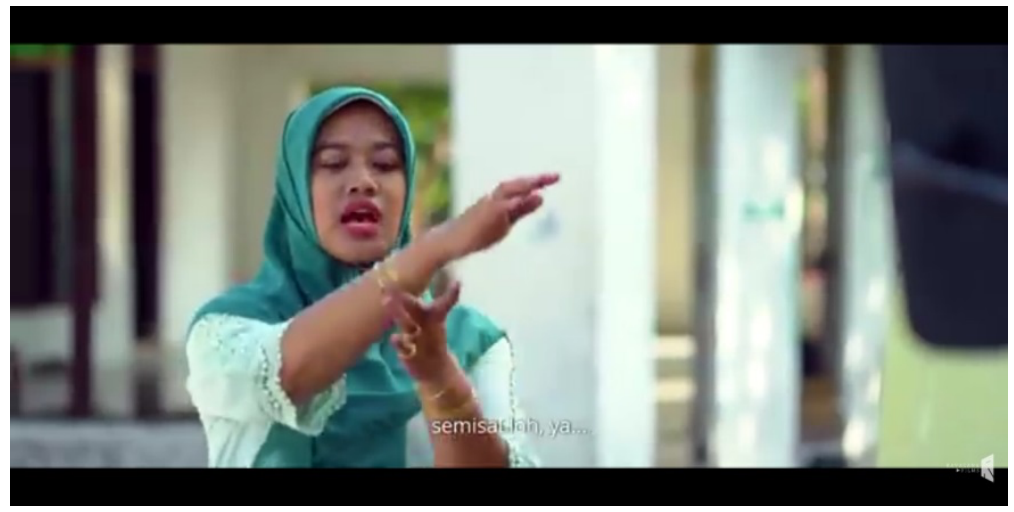

Gambar 3. Perempuan sebagai Tukang Pamer (Scene Menit ke 00:10:32 - 00:11:00)

Level Denotasi. Bu Tejo memegang perhiasan gelang dan cincinnya. Level Konotasi. Bu Tejo memamerkan perhiasan gelang dan cincinya di hadapan Gotrek (Supir Truk) dan Bu Yun. Makna Mitos dalam gambar tersebut adalah $\mathrm{Bu}$ Tejo ingin memberikan pesan kepada Gotrek agar bisa menjadi tim sukses suaminya menjadi lurah.

Peran $\mathrm{Bu}$ Tejo dalam durasi video ini menggambarkan sosok ibu-ibu pamer. Pembawaannya dalam memerankan sosok yang julid serta suka pamer dinilai sangat sukses, terutama dialek dan logat yang digunakan juga sangat relevan. Tergambar dalam film redaksi kalimat: "Kuwi ngono kalebu sogokan. Wis wis balekne wae." (Nah kan bener! Itu tadi sogokan, tuh. Udah, balikin aja daripada bikin masalah).

Hal yang cukup menarik perhatian penonton adalah sikap $\mathrm{Bu}$ Tejo yang ternyata diam-diam memiliki misi lain. Dia berusaha mengenalkan sosok suaminya, Pak Tejo, yang rencananya akan mencalonkan diri sebagai lurah di kampungnya, menggantikan Bu Lurah yang kondisinya kini sering sakit-sakitan. Bu Tejo bahkan memberikan amplop berisi uang khusus buat Gotrek, supir truk tersebut. 


\subsection{Pengaruh Internet di Kalangan Ibu-ibu}

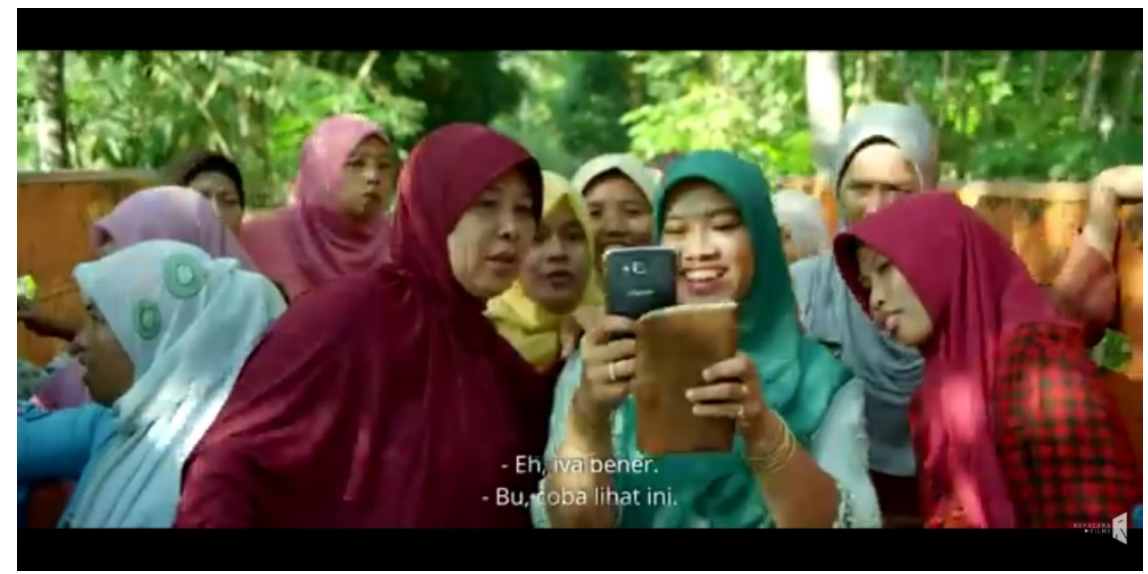

Gambar 4. Pengaruh Internet di Kalangan Ibu-ibu (Scene Menit ke 00:02:10 - 00:02:34)

Level denotasi. Bu Tejo membuka handphone (HP) dan disasksi oleh Ibu-ibu. Level Konotasi. Bu Tejo membagikan informasi mengenai Dian di facebook kepada Ibu-ibu dan memberikan pesan bahwa HP untuk media informasi. Adapun makna mitos dalam gambar tersebut adalah Bu Tejo memberikan informasi melalui internet dan media sosial.

Sehingga dari gambar tersebut terjadi pengaruh besar terhadap kaum ibu-ibu akan kegunaan dan fungsi HP itu sendiri, seperti yang diungkapkan pada video, "Mangkane nduwe hp ki ora mung gawe gaya thok. Nanging gawe golek informasi ngono lho" (Makannya, punya HP itu jangan cuma buat pajangan saja, tapi buat cari informasi juga gitu loh.) Ungkap Bu Tejo.

Bagian penting dari film ini adalah cara bagaimana perempuan pengguna internet menghadapi gangguan informasi. Kini banyak orang menggunakan HP canggih, bukan hanya sekadar pamer atau berlomba-lomba update kepemilikan HP merek terkini. Tapi perlu diperhatikan juga fungsi dari HP tersebut. Salah satunya untuk menggali informasi.

Yu Ning yang sendirian dalam upaya memerangi kekacauan informasi, berkata, "Berita sangka internet ki ya kudu dicek sik. Ora mung liwat terus dileg wae" (Berita dari internet itu ya harus dicek dulu, jangan kita telan mentah-mentah begitu saja). Namun pada akhirnya, ia digambarkan bersalah karena tidak mengecek apakah Bu Lurah bisa menerima pengunjung selama di ICU. Sementara itu, Bu Tejo, sumber utama disinformasi, menang atas Yu Ning. Di akhir film, suara Yu Ning dibungkam dengan ungkapan "Sregepa maca berita sangka internet, dadine lek dijak ngomong ki nyambung" tutur $\mathrm{Bu}$ Tejo.

Tidak ada perempuan lain yang membela posisi Yu Ning saat dia menantang Bu Tejo. Oleh karena itu, film tersebut melanggengkan gagasan, kebanyakan perempuan lebih memilih untuk tetap diam ketika dihadapkan pada rumor atau pesan yang dibuat-buat, karena mereka menghargai harmoni daripada kebenaran.

Adapun ungkapan Yu Ning "Berita sangka internet ki ya kudu dicek sik. Ora mung liwat terus dileg wae" (Berita dari internet itu ya harus dicek dulu, jangan kita telan mentah-mentah begitu saja) (video durasi 00:05:05) Pada ungkapan tersebut, penonton diperingatkan untuk menjadi penikmat internet yang cerdas. Agar tidak termakan hoaks. Pembungkaman satu-satunya pendukung literasi digital 
dalam film tersebut, Yu Ning, akhirnya menggambarkan masyarakat terjebak dalam kekacauan informasi, dan tidak dapat berbuat banyak tentangnya. Adapun yang mengecewakan, itu juga menggambarkan perempuan sebagai satu-satunya sumber gangguan informasi, ketika laki-laki sama bersalahnya.

\subsection{Perempuan yang Belum Menikah di Usia matang menjadi bahan fitnah}

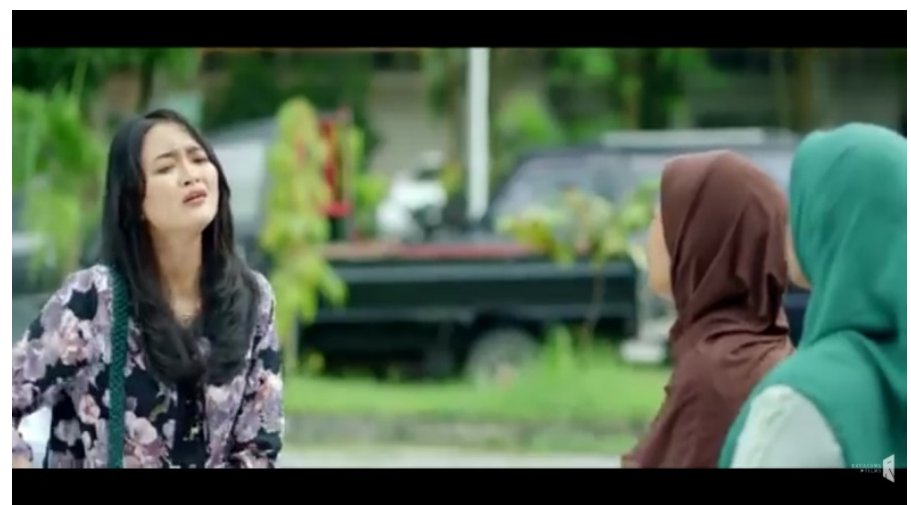

Gambar 5. Perempuan Muda (Scene Menit ke 00:25:30 - 00:26:06)

Level denotasi pada pada gambar terlihat Dian sosok perempuan muda sedang berbicara dengan $\mathrm{Bu}$ Tejo dan Bu Yu Ning. Level Konotasi yang ingin disampaikan pada gambar ini adalah Dian memberikan pesan kepada Bu Tejo dan Bu Yu Ning bahwa Ibu lurah sedang berada di ICU dan tidak bisa dijenguk. Adapun mitos yang ada adalah reaksi Dian saat kedatangan Ibu-ibu dia meminta maaf dan memohon untuk tidak menjenguk Ibu Lurah dikarenakan sedang berada di ICU.

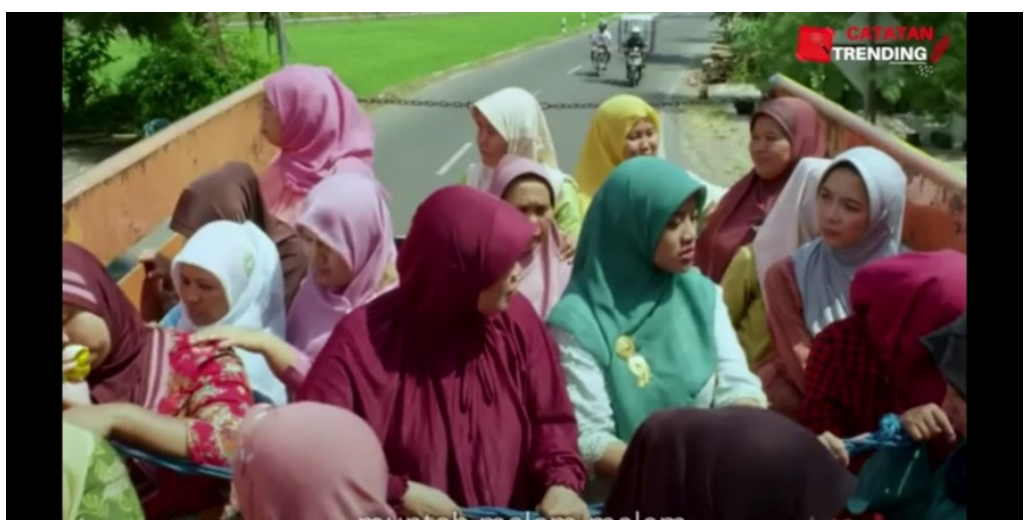

Gambar 6. Gosip Dian (Scene Menit ke 00:00:40 - 00:05:00)

Level Denotasi. Ibu-ibu sedang berbincang-bincang membicarakan seseorang. Level Konotasi. Ibuibu sedang membicarakan sosok Dian, perempuan muda yang belum kunjung menikah dan menjadi keresahan kaum ibu-ibu. Adapun makna mitosnya adalah Ibu-ibu membicarakan Dian soal kehidupanya.

Dalam perjalanannya, ibu-ibu itu berdiskusi tentang perempuan muda yang cantik, Dian, dan mempertanyakan hubungannya dengan putra Bu Lurah, Fikri. Salah satu ibu, Bu Tejo, mengolok-olok atau mengritik hampir setiap aspek kehidupan Dian: profesinya, hubungan, pendidikan, kesehatan, harta benda, penggunaan susuk, dan kekayaan ibunya. Bu Tejo menggunakan informasi ini untuk mencoba meyakinkan ibu-ibu lain bahwa Dian adalah "gadis nakal". Padahal, kisah Dian yang 
ditampilkan di akhir film tersebut menyertakan pesan moral akan kemerdekaan dalam kemandirian, yang seharusnya dimiliki perempuan, tanpa bergantung pada laki-laki.

Dalam cuplikan tersebut, terdapat percakapan yang mengandung makna yang dalam seperti ungkapan Bu Tejo "Wong wis umurane kok ya ora ndhang rabi” (Orang sudah berusia matang kok belum juga menikah). Kalimat ini sering didengar di kalangan masyarakat desa. Terlebih bila melihat perempuan yang sudah berumur dan belum kunjung menikah. Hal ini dapat menjadikan polemik di masyarakat, adanya kontradiksi antara dua pemahaman dalam masyarakat. Di zaman emansipasi saat ini, meskipun laki-laki menjadi tulang punggung keluarga, namun perempuan bisa menjadi peran yang sama untuk bekerja, juga pemahaman masyarakat tentang ketimpangan antara laki-laki yang usia matang dengan perempuan yang usianya matang memiliki paradigma yang berbeda di masyarakat, masih begitu banyak anomali yang terjadi di masyarakat. Mereka beranggapan perempuan yang sudah matang dan belum menikah di dalam lingkungan masyarakat itu dapat mengakibatkan keretakan rumah tangga disekitarnya.

\subsection{Perempuan Mampu bekerja di Ranah Publik}

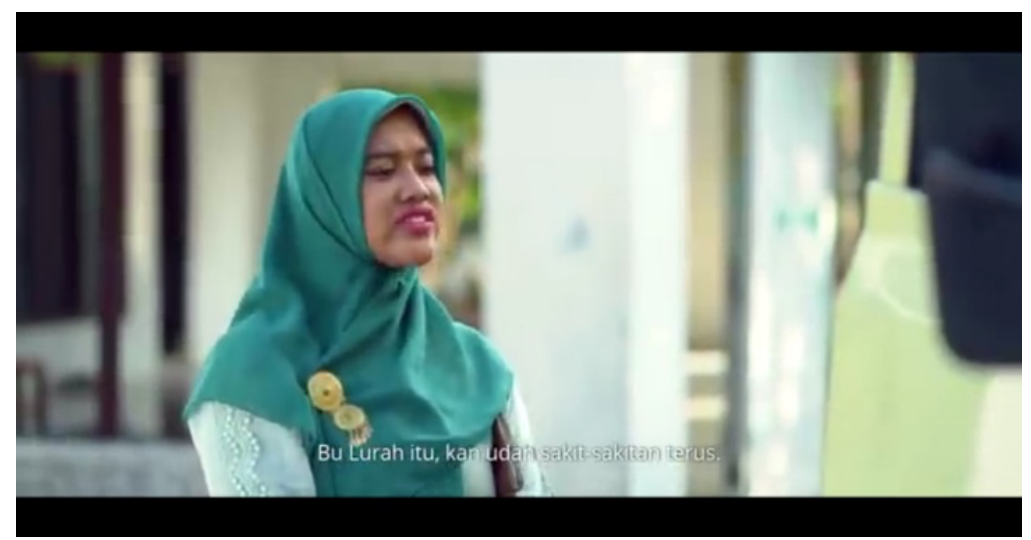

Gambar 7. Bu lurah (Scene Menit ke 00:11:30 - 00:11:38)

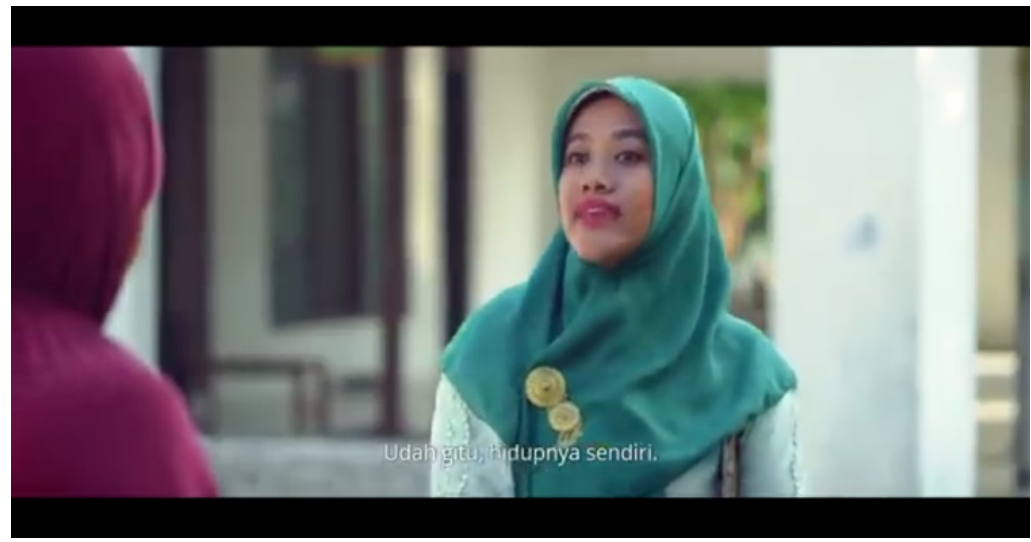

Gambar 8. Bu Lurah (Scene menit ke 00:11:42 - 00:11:50)

Level Denotasi. Bu Tejo bercerita kepada Gotrek dan Bu Yu Ning. Level Konotasi. Bu Tejo menceritakan kondisi bu lurah kepada Gotrek dan Yu Ning. Adapun makna mitosnya adalah Bu Tejo memberikan isyarat bahwa suaminya untuk menjadi lurah karena membeberkan kondisi Bu lurah saat ini kepada Gotrek dan Yu Ning. 
Sebagian besar dalam film ini berfokus pada representasi perempuan. film itu menantang stereotipe perempuan, khususnya melalui karakter $\mathrm{Bu}$ Lurah seorang perempuan yang dapat merambah ke ruang publik. Ada juga memperkuat stereotipe perempuan sebagai penggosip dan hanya bisa nyinyir tentang keberhasilan seseorang.

\section{Kesimpulan}

Berdasarkan hasil penelitian, peneliti menyimpulkan lima temuan bagaimana potret perempuan dalam film Tilik direperentasikan. Pertama, perempuan sebagai tukang gosip. Kedua, perempuan sebagai tukang pamer. Ketiga, pengaruh internet terhadap ibu-ibu. Keempat, perempuan yang belum menikah di usia matang menjadi bahan fitnah. Kelima, perempuan mampu bekerja di ranah publik. Kelima temuan ini bukanlah suatu usaha peneliti untuk melakukan generalisasi terhadap perempuan. Dengan kelima unsur yang dimiliki perempuan, ternyata menyimpan makna yang bisa diambil sebagai pelajaran hidup.

Secara global film ini menggambarkan kekuatan perempuan dengan cara yang negatif. Akan tetapi terdapat pula nilai positif yang dapat diambil, diantaranya tradisi masyarakat desa yang saling peduli saat seseorang sakit atau tertimpa musibah, gotong royong untuk meringankan beban seseorang yang terkena musibah dan memiliki pribadi solutif ketika terjadi dinamika. Dimana tradisi ini sulit ditemukan dalam kehidupan perempuan di kota-kota besar. Juga pesatnya perkembangan teknologi di kalangan ibu-ibu, serta pesan moral akan kemerdekaan dalam kemandirian, yang seharusnya dimiliki perempuan.

\section{Referensi}

Anggraini, D. (2016). Stereotip Perempuan dalam FIlm Get Merried: Analisis Semiotika Roland Barthes . EJournal Ilmu Komunikasi, 176-185.

Balci, V. \&. (2017). What Sprts Advertising Tell to Us? Semiotic Analysis. Journal of Education and Training Studies, 5.

Chandler, D. (2007). Semiotic: The Basics (2th ed.). New York: Routledge.

D. Jones. (1980). Gossip: Notes on women's. Retrieved from https://doi.org/10.1016/S01480685(80)92155-7: https://doi.org/10.1016/S0148-0685(80)92155-7

Effendy, O. U. (1986). Dinamika Komunikasi. Bandung: Remaja Rosdakarya.

Hartoyo, E. K. (2018). Potret Perempuan Parangtritis dalam Film Siti. Jurnal Avant Garde, 91-101.

Kintoko, W. I. (2020). Warta Kota. Retrieved from Setelah 16 Hari Diunggah di Kanal Youtube Ravacana Films, Film 'Tilik' Telah Ditonton 20 Juta Views : https://wartakota.tribunnews.com/2020/09/01/setelah-16-hari-diunggah-di-kanal-youtuberavacana-films,-film-tilik-telah-ditonton-20-juta-views

Perdana, D. D. (2014). Strereotip Gender dalam Film Karenina. Jurnal Interaksi, 123-130.

S. E. Merry. (1984). Rethinking Gossip . Retrieved from https://doi.org/10.1016/B978-0-12-102801$5.50016-9$

Sobur, A. (2009). Semiotika Komunikasi. Bandung: Remaja Rosdakarya. 
Warsilah, H. (2020). Transformasi Sosial Kultural Wong Ndeso Melalui Film Tilik dalam Konsep Lefebre. Jurnal Masyarakat dan Budaya. 